\title{
Még egyszer Naszvad (Nesvady) honfoglaló sírjairól
}

\author{
1TÓTH GÁBOR \\ 'ELTE SEK Savaria Biológiai Tanszék, H-9700 Szombathely, Károlyi G. tér 4. \\ e-mail: tgabor.humbiol@gmail.com
}

То́тн, G.: Once again Naszvad (Nesvady) Conquering graves

Abstract: The paper presents the data revealed from the anthropological examination of the remains of 36 persons dug up in Slovakia. Naszvad surrounding area since the 1930s, known conquerors graves. People living in the area of biological characteristics are uniform. Examination of the 1970-71's excavations bone material confirms this understanding. The bad conditions of mortality may have caused the spread of tuberculosis. A woman's skull symbolic trephination examined (ritual healing method).

Keywords: Early Hungarians, tuberculosis, cranial surgery

\section{Bevezetés}

A Szlovák-alföld területe, mint vándorlási útvonal, és mint letelepedésre alkalmas, a Duna és a Vág (valamint mellékfolyói) által vízi utakkal is rendelkező sík vidék, bővelkedik régészeti emlékekben. A Nyitra - Érsekújvár Komárom tengely mentén, illetve a Nyitra - Esztergom kora középkori útvonal térségéből ismertek a régészeti szakirodalomban tárgyalt honfoglaló leletek, amelyeket a magyarországi Kisalföld lelőhelyeivel összefüggésben is szoktak ismertetni. ${ }^{1}$ Naszvad határából az 1930-as évek szőlőműveléssel kapcsolatos leletmentései óta ismerjük honfoglaló magyarok sírjait, ${ }^{2}$ amelyekről 1941-ben jelent meg az első antropológiai vizsgálat eredménye. ${ }^{3}$ Ezt követően, 1943-ban kora Árpád-kori több rétegű templom körüli temető egy részét, mintegy 275 sírt (11-18. század) tártak fel. Ezek a régészeti és embertani maradványok az Érsekújvári Múzeumban a háború során teljesen megsemmisültek. A háborút követő időszakból, Naszvadról (1954-ből) van még honfoglaló magyar sírról bizonytalan adat. ${ }^{4}$ Jelen vizsgálat az 1970-1971-es ásatás sírjainak humán csontanyagának vizsgálatával az egykori népesség biológiai rekonstrukciójához szolgáltat további ismereteket.

\section{Anyag és módszer}

A vizsgálat anyagát az 1970-1971-ben feltárt és régészetileg már ismertetett Naszvad-Rókalyuk lelőhely ${ }^{5}$ sírjainak csontanyaga jelenti. Az embertani anyag a komáromi Duna Menti Múzeum régészeti gyűjteményében található. 6 A régészeti közlés 30 sírt ismertet (a sírok 1-30-ig számozva). Leírásukban embertani alapadatként a nemi hovatartozás és az életkor korcsoporti besorolása is szerepel. Ezeket az adatokat a közléshez Maria Vondráková szolgáltatta, a közleményben további embertani adatokat nem ismertetve. ${ }^{7}$ Az eredeti csomagolásban megőrzött csontanyag sírjainak számozása a tanulmánynak ellent mondva 1-től 16-ig folyamatos, az 5-től 12-ig számozott sírok sírszámai pedig duplán kerültek kiadásra. Sírszámmal jelölve a 16-os sírt követően már csak a 25. sír anyaga szerepel. Ezen túl két további sír csontanyaga sírszám nélküli, valamint további sírok és csontok köthetők a „Sonda A, B, C" azonosító feliratokhoz. Mindösszesen 36 személy maradványait és 2 szórványnak tekinthető vázrészletet lehetett beazonosítani, amelyeket nem sikerült a vizsgálatok után minden esetben megfeleltetni a régészeti közlés sírleírásainak. Az embertani vizsgálat Éry Kinga ${ }^{8}$ és Rainer Knußmann ajánlásait követve történt.

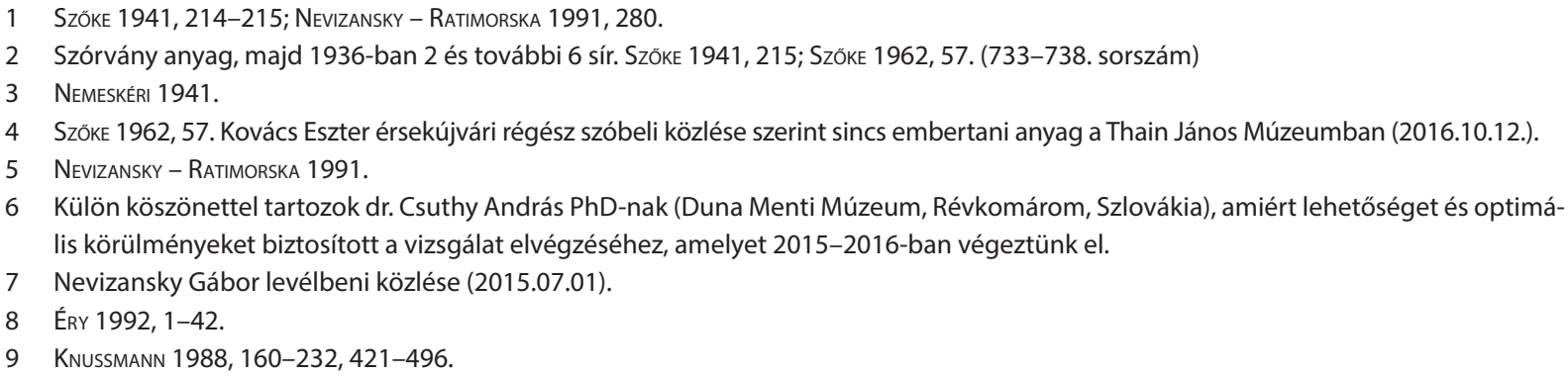




\section{Eredmények}

A régészeti közlés és a vizsgált csontanyag számozása közti anomáliák miatt az egyes sírok leírásától és a méretek közlésétől eltekintek. Az eredmények közül csupán néhány fontosabbat emelnék ki az egykor élt népességgel kapcsolatban.

A 36 vizsgált személy közül 15 nő, 9 férfi, 5 esetben pedig a hiányos és rossz megtartású felnőtt maradványok nemi hovatartozását nem sikerült eldönteni. Gyermeki maradványok 6 esetben kerültek vizsgálatra, egy sírban pedig (Sonda A3) női csontvázzal együtt egy újszülött, vagy pedig egy még meg nem született érett magzat csontjai őrződtek meg.

Paleodemográfiai számítások alapján, ${ }^{10}$ a kis elemszám ellenére, korrekciós modellek segítségével hozzávetőleges becslések tehetők. Ez alapján a születéskor várható élettartam alacsony, mindössze 18-19 év. Férfiak esetében a várható élettartam a 15. életév betöltése után még további 20 év, nők esetében pedig további 18 év. Ennek oka, hogy a halandósági csúcs férfiaknál egy nagyobb kiugrással 30-34 év körül-, majd egy kisebb csúccsal a 40-44 év körüli életkorban jellemző. A nők halandósági csúcsa a szüléssel és a gyermekágyi fertőzésekkel kapcsolatban 25-29 év körül magas, majd később az 50-54 éves kor körüli időszakban jellemző egy kisebb halandósági csúcs is. lly módon 45-49 éves korig a férfiaknak jobb a túlélése, majd ezt követően a nők túlélési mutatói lesznek jobbak.

A koponyák jellemző méreteit csupán néhány esetben sikerült felvenni, ily módon a statisztikai összehasonlításokhoz szükséges minimális elemszámú vizsgálati adat nem áll rendelkezésre. Annyi megállapítható 2 férfi és 6 nő koponyaméreteinek klasszifikációja alapján, hogy a koponyák jellemzően a széles tartományba tartoznak. A koponyajelző 2 férfi és 7 nő méreteiből számítva általában a középszéles kategóriába tartozik. A hosszúcsontok méreteiből számított testmagasság értékek ${ }^{11} 7$ férfi méretei alapján 171,2 centiméter átlagot adnak; ez Martin szerinti magas termetérték. Az ebből a szempontból vizsgálható 8 nő átlagos testmagassága 154,1 centiméter; ez a Martin szerinti középmagas kategóriába tartozó érték.

Taxonomiailag vizsgálva'12 1 férfi és 6 nő maradványai alapján a nordikus, az europomongolid/szinid, és a mediterrán típusok határozhatóak meg.

Epigenetikus jellegek mint Worm-csontok, lambda csont, sutura metopica, basion táji csontkinövés (1.ábra), nyakcsigolya variációk (2.ábra) és foramen olecrani képében jelennek meg. Elöfordulásuk esetleges, a közösség tagjai közt nem utal szoros és halmozott vérségi kapcsolatra.

A letelepedett életmódra és szénhidrát-dús táplálkozásra ${ }^{13}$ utal a fogazat állapota; jellemzően magas életbeni fogvesztéssel és cariessel már fiatal életkorokban is (3. ábra). Hiánybetegségre, vashiányos vérszegénységre utaló jelként két esetben cribra orbitalia; a csontos szemüreg lyukacsos átalakulása figyelhető meg. A fokozott fizikai igénybevétel 6 esetben a csigolyák degeneratív elváltozását okozta, 1 esetben féloldali terhelés következtében - a csigolyák aszimmetriáját is előidézve. A fizikai stressz felső végtagokon 7 esetben, a sarokcsontokon 8 esetben okozott jellegzetes elváltozásokat. Szülés-

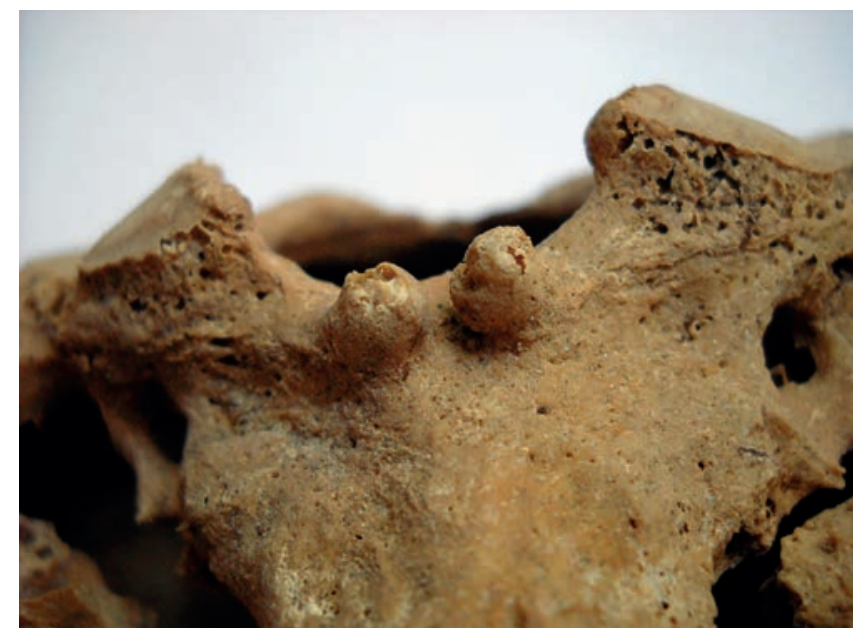

1. ábra. Csontkinövés a basion tájékon nyomok a medencén két esetben voltak megfigyelhetőek.

Neurológiai kórképre, a jobb alsó végtag sorvadására utaló méretbeli különbségek egy esetben, míg egy másik esetben az aszimmetrikus femur szintén valamely neurológiai kórképre, esetleg sérülésre utal.

A csigolyák spondylolisthesise lumbalis szakaszon 2 személynél, a sacrum spina bifidája szintén 2 esetben, sacralisatio (4. ábra) pedig 1 esetben fordult elö.

A gyógyult törések és sérülések 1-1 esetben fordultak elő. Ezek localisatioja: nyakcsigolya törése (5. ábra), bordatörés, humerus törése, ulna törése, kézközépcsont törése, lábközépcsont törése.

10 ACSÁdI - NeMESKÉRI 1970.

11 SJøVOLD 1990.

12 LIPTÁK 1980, 254-302.

13 Honfoglalás kori sírok ételmellékleteiből, Balatonudvari lelőhely anyagában, sikerült kimutatni Tobischka Katalin folyamatban lévő vizsgálataiban kásamaradványokat. 


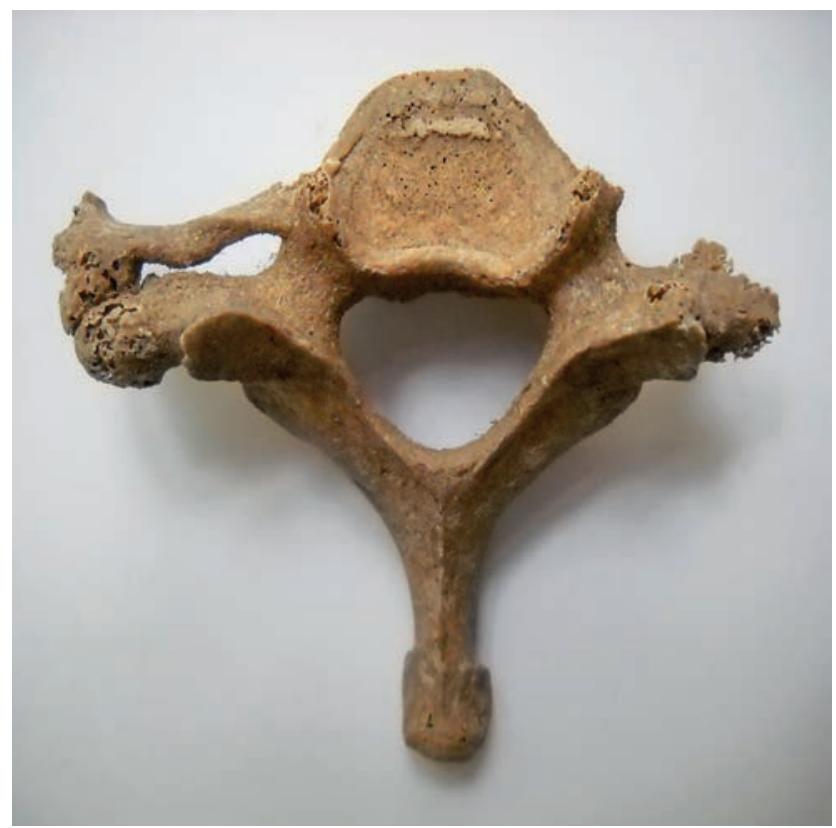

2. ábra. Nyakcsigolya variáció
Tuberculosisra utaló csontelváltozások elsősorban a csigolyákon jelentek meg. Három személynél jellegzetes elváltozások figyelhetőek meg a csigolyatesteken (caries) (6. ábra), egyiküknél a csigolya összeroppanásával, ék alakú csigolya kialakulásával (7. ábra). Egyiküknél a koponyán is jellegzetes elváltozás, pitting alakult ki (8. ábra). Egy negyedik személynél a csípőízület típusos tuberculoticus elváltozása alakult ki a caput femoris deformitásával és az ízületi vápa mészfelrakódásos elváltozásával (9-10. ábra). További esetekben bizonytalan aetiologiájú, de feltehetően szintén tuberculosisra visszavezethető gyulladásos nyomok észlelhetőek a tibiákon (11. ábra), ulnán és a lábközépcsontokon.

Más egészségügyi problémák indirekt gyógyításának jeleként a 8. sírban nyugvó fiatal nő homlokcsontjának közepén 13 milliméter átmérőjü, kerekded, körívet nem teljesen záró, gyógyulási nyomot nem mutató jelképes trepanáció nyoma (12-13. ábra) látható. Feltehetően kés hegyével készült. A jobbkezes gyógyító az óra járásával megegyező irányban kanyaríthatta a mélyebben induló (corticalis alá hatoló), majd a végére sekélyebbé váló csontsebet.

Végül ismét meg kell említeni az anya és újszülöttje (vagy érett magzata) temetkezését. A fiatal nő jobb felkarcsontjának könyök tájéka régi töréssel leválasztódott, a két csontdarab egymástól eltávolodva az évszázadok folyamán teljesen eltérő színúvé vált (14. ábra) - ez eltérő talajviszonyok színező hatását mutatja. Ez a régi törés, aminek következtében az epiphysis és a diaphysis eltávolodott egymástól, korai bolygatásra, esetleges sírrablásra utalhat.

\section{Megbeszélés}

A Naszvad környékéről származó szórványos irodalmi közlések felhívják a figyelmet a Szlovák-alföld honfoglalás kori embertani leleteinek fontosságára. Éry Kinga a Kárpát-medence adott időszakra vonatkozó embertani képének meghatározásához ${ }^{14}$ erről a területről is gyűjtött adatokat. 1990-ben minisztériumi engedéllyel végzett vizsgálatokat Pozsonyban, Nyitrán és Brünnben. Honfoglalók maradványait csak a pozsonyi gyűjteményben talált, ${ }^{15}$ innét közölte Naszvad-Partok-dűlőről három férfi koponyaadatait is. ${ }^{16}$ Elemzése szerint ${ }^{17}$ a 9. század végének és a 10. század első felének Kárpát-medencei népességét két öszszetevő alkotta: a keletről érkezett honfoglalók és a helyben talált lakosság. A dél-szlovákiai helyben lévő avarok koponyajelzőjüket tekintve hosszú fejű csoportok voltak. Megérték a honfoglalást és a későbbiekben beolvadtak az Árpád-kor népességébe. A Vág és Nyitra folyók közti térség honfoglalói embertanilag külön regionális egységet alkotnak, amely a Duna-Tisza közi és a Felső-Tisza-vidéki honfoglalók csoportjaival mutat kapcsolatot. Ez a három csoport egy főcsoportot alkot, amelyet a koponya kifejezett szélessége jellemez. Körükben az europo-mongolidok aránya legalább 40\%. Eredetüket tekintve a Dontól keletre eső, részben európai, részben ázsiai füves puszta késő vaskori népességeivel mutatnak hasonlóságot. Másik főcsoportot a keskeny koponyájú, mindössze 6\% europo-mongolid összetevőt tartalmazó Észak- és Kelet-dunántúli honfoglalók jelentenek, összevonva a hozzájuk nagy fokban hasonló Körös-Maros közi népességgel. A dunántúli népcsoportok a Dontól nyugatra és a Fekete-tengertől északra eső füves és a vele szomszédos ligetes puszta határvidékének vaskori népességére hasonlítanak. Feltételezhető, hogy ez a népesség alárendelt szerepet játszott a honfoglalók csoportjain belül. A férfiak és nők hasonló jellemzőkkel bírnak, tehát a honfoglalók nem nőhiánnyal érkeztek. Testmagasságuk a nagy-közepes termetosztályba tartozott.

A Naszvad-Rókalyuk lelőhelyről vizsgált maradványok alapján nyert eredményeink párhuzamba állíthatók a regionalitásra vonatkozó megállapításokkal. A férfiak és a nők egyaránt azonos koponyajellemzőkkel bírva a széles koponyájú csoport jellegzetességeit és testmagasságát mutatják. A letelepedett népesség sérülései

14 ÉRY 1994

15 Éry Kinga levélbeni közlése (2016.10.05.).

16 ÉRY 1994, 295.

17 ÉRY 1994, 217-224. 


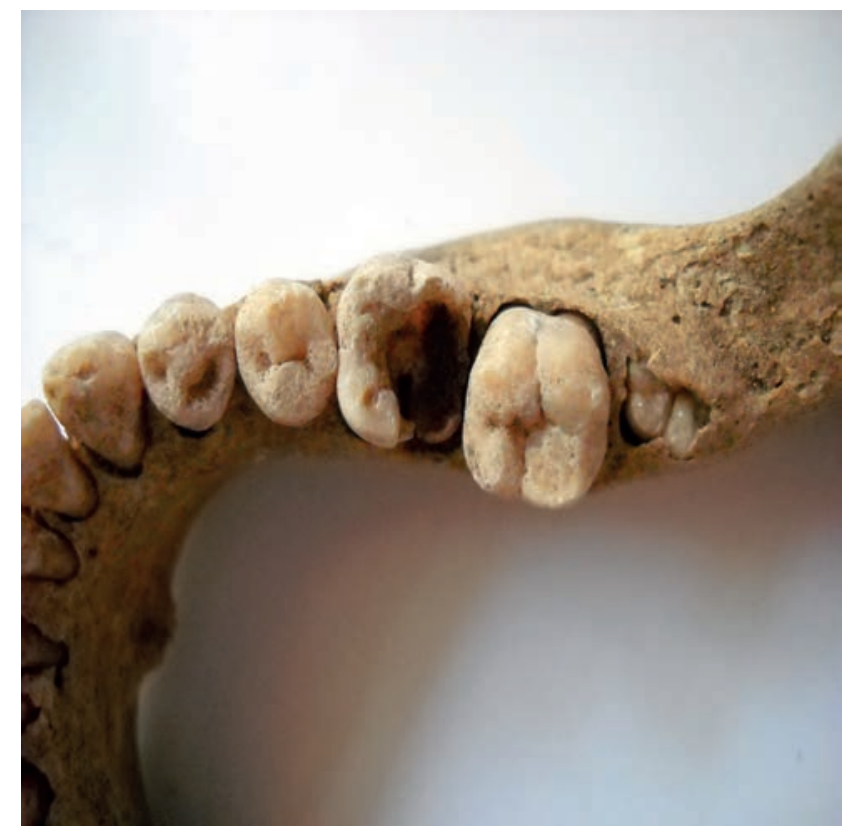

3. ábra. Caries nem magyarázzák a rossz halandósági viszonyokat. Annak hátterében a tuberculosis vélhetően magas gyakoriságát tarthatjuk vezető halálokként. A cseppfertőzéssel terjedő Mycobacterium tuberculosis általában pulmonaris formában okoz megbetegedést, de a betegek mintegy 5\%ánál kialakulhatnak a jellegzetes csontelváltozások is. ${ }^{18}$

A honfoglalók koponyasebészetének, a trepanációk végzésének a Szlovák-alföldről is ismertek leletei. ${ }^{19}$ Külön érdekességnek tekinthető a jelképes trepanáció, amely a közvetett gyógyítás egyik eszköze. ${ }^{20}$ A Naszvadon feltárt női koponya homlokán megfigyelhető jelképes koponyalékelés technikája megfelel a késsel végzett beavatkozásnak. ${ }^{21} \mathrm{~A}$ bekarcolást azonban ebben az esetben nem követte a körkörös kivésés és a csontrész kipattintása. Mivel gyógyulási nyom nincs, elképzelhető, hogy a beteg halála miatt nem került már sor a művelet befejezésére.

Köszönetnyilvánítás: Duna Menti Múzeum (Komarno) Vezetőinek és Munkatársainak a támogató segítségért.

\title{
Once again Naszvad (Nesvady) Conquering graves
}

\begin{abstract}
GÁBORTÓTH
Sparse literature data from the Naszvad region bring to limelight the importance of the anthropological artifacts of the Eastern Slovak Lowland from the Hungarian Conquest Period. According to the assay of Éry Kinga the Avars of Southern Slovakia living in the Age of the Hungarian Land Taking have melt into the Arpadian Age population. The conquerors of the region between the rivers Vág and Nitra constitute a distinct regional anthropological entity, related to some groups of conquerors of the Danube-Tisza Interfluve and the Upper Tisza Region. Among the latter ones, the percentage of Europo-Mongoloids is at least 40 per cent. As regard to their origin, they show some similarities to the late Iron Age population living on the partly European, partly Asian steppes located the East of the river Don. Their stature was in the tall-medium range.

Our data gained from the human remains of the archaeological site Naszvad Rókalyuk correspond with the above statement concerning the regional particularity. Both men and women are characterized by common craniofacial parameters. They show the characteristics and stature of broad skull group. The injuries of the settled population do not explain the high mortality rate. Its background might be the presumably high prevalence of tuberculosis as number one cause of deaths.

Traces of cranial surgery among the Hungarian Conquest Period population can be observed on human remains from the Eastern Slovak Lowland, too. The ritual trepanation on the forehead of a female skull dug up at Naszvad seems to have been performed by a trepanation knife technique.
\end{abstract}

18 MARCSIK ET AL. 2009, 10-11.

19 VondRÁKová 1993.

20 ÉRY 1994, 222; VÁRADI ET AL. 2015, 91-92.

21 NemeskérI - ÉRY - KralovÁnszKY 1960. 


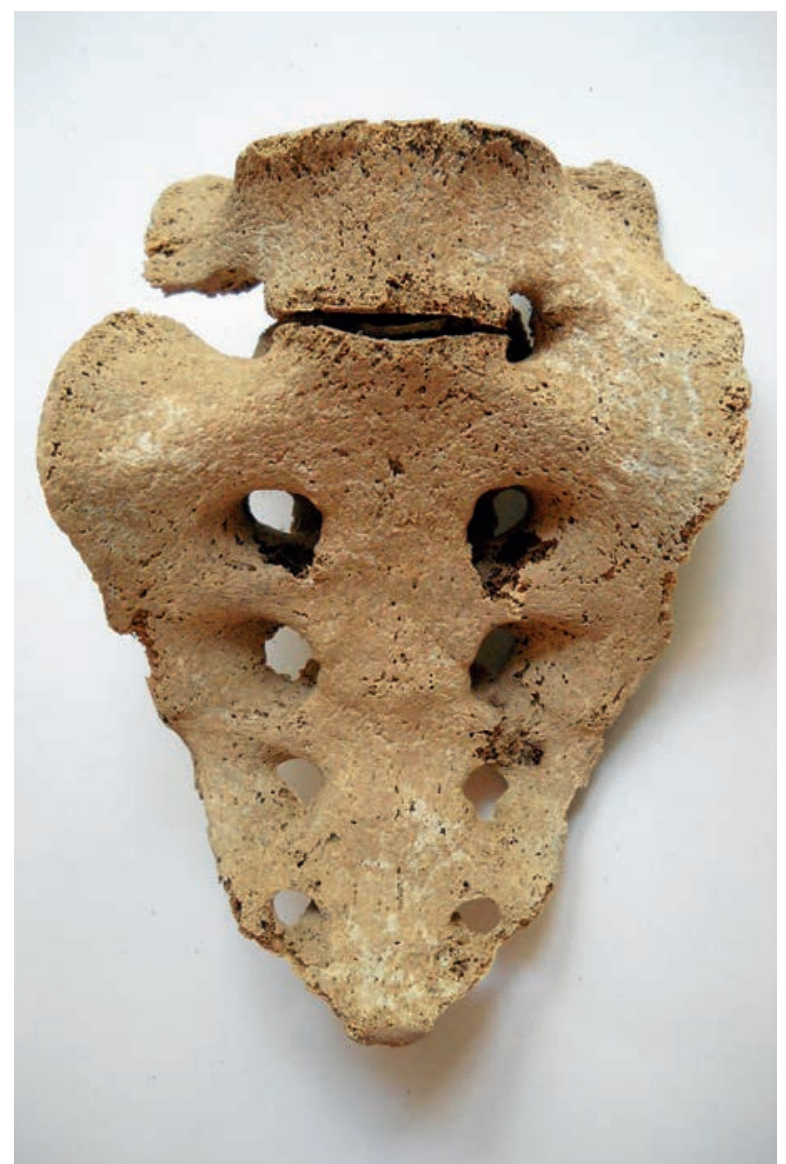

4. ábra. Sacralisatio

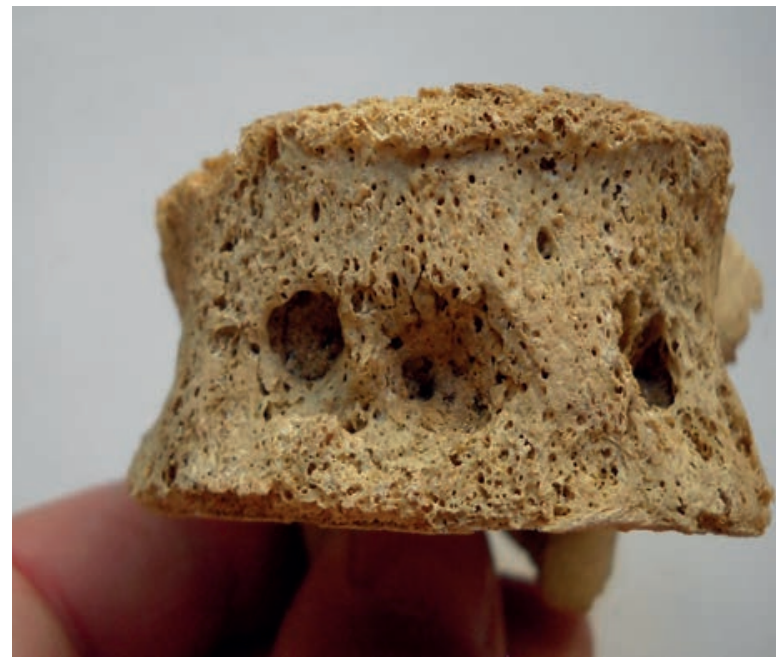

6. ábra. Csigolya tuberculoticus elváltozása (caries)

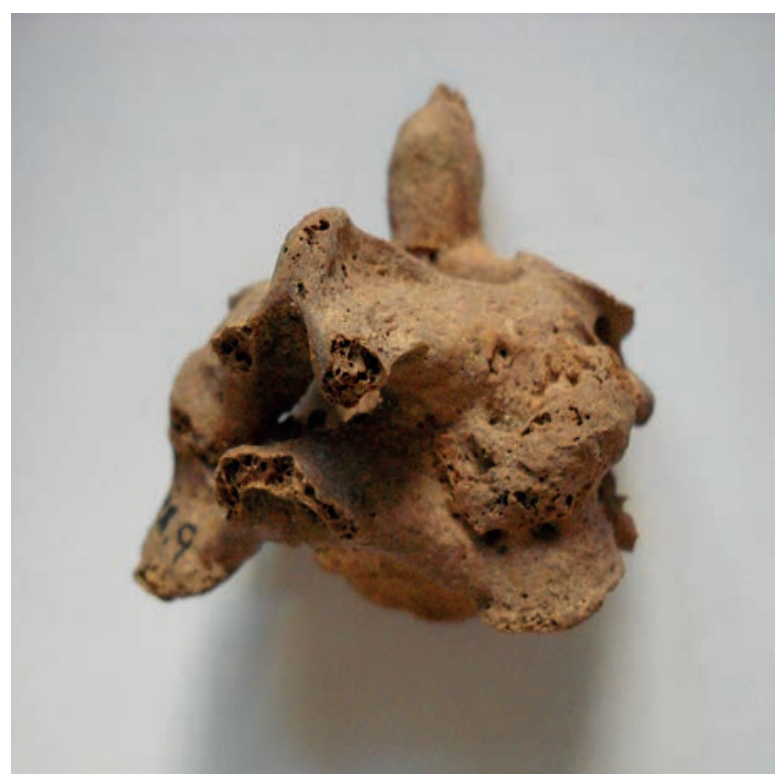

5. ábra. Nyakcsigolya törése

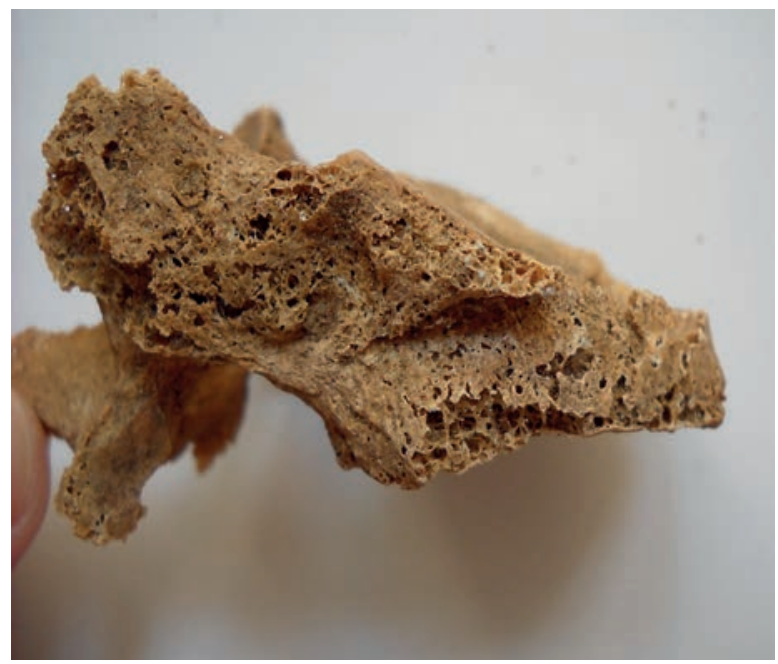

7. ábra. Ék alakú csigolya 


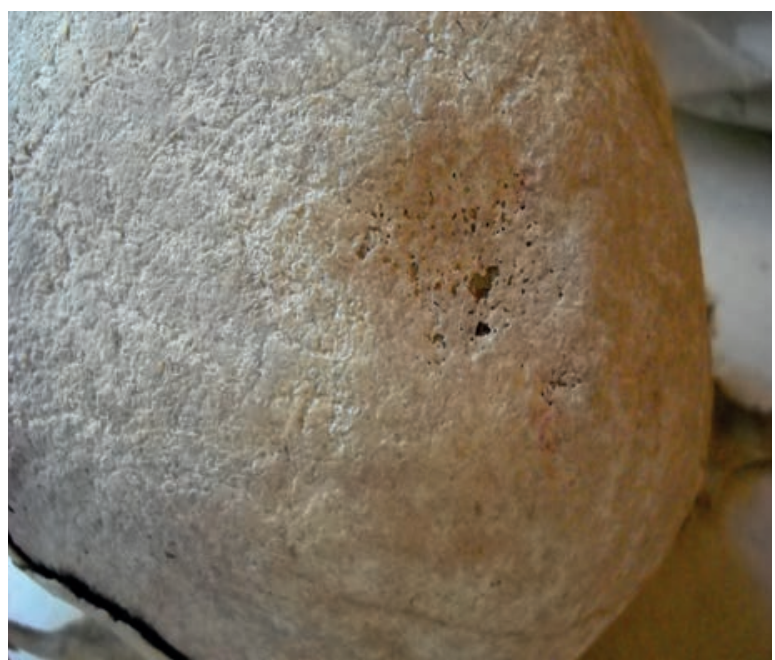

8. ábra. Pitting a koponyán (tuberculosis)

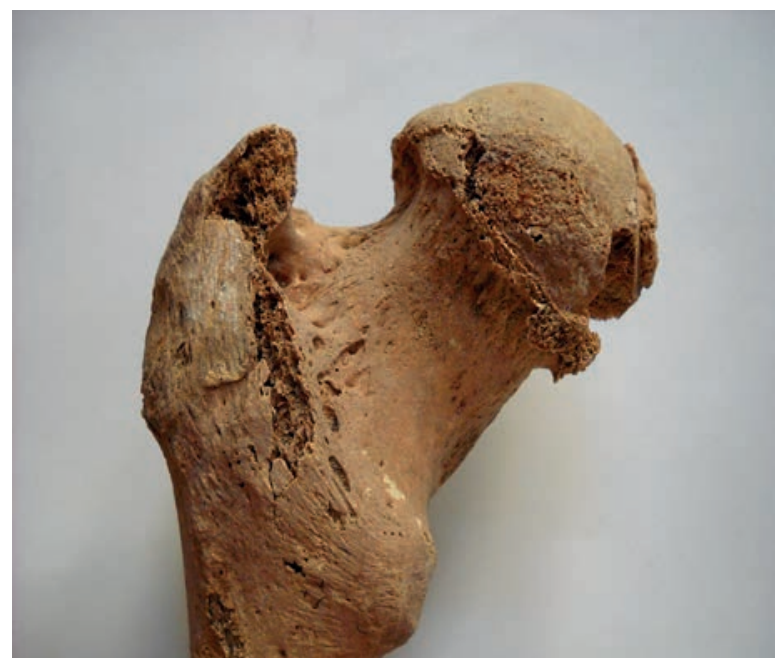

9. ábra. Csípőízület elváltozása (tuberculosis)

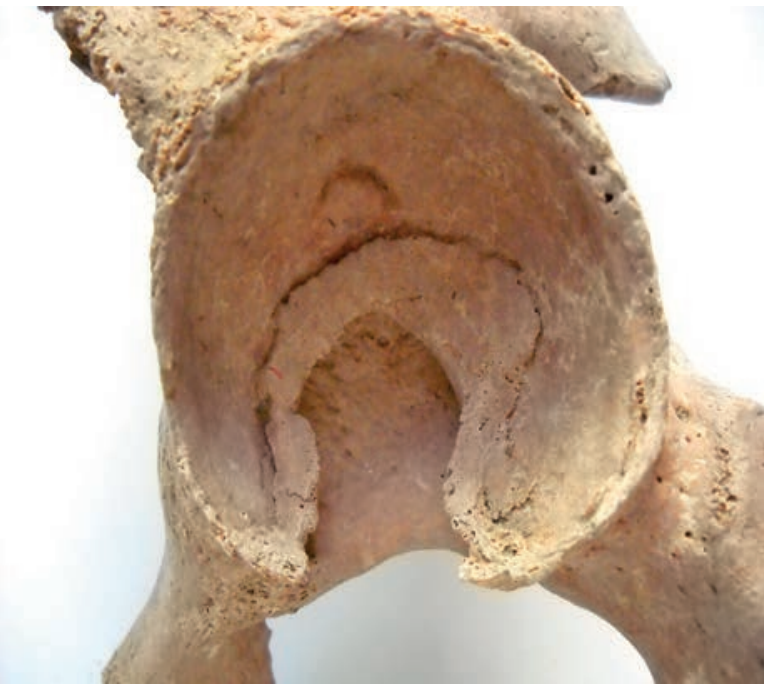

10. ábra. Csípőízület elváltozása(tuberculosis)

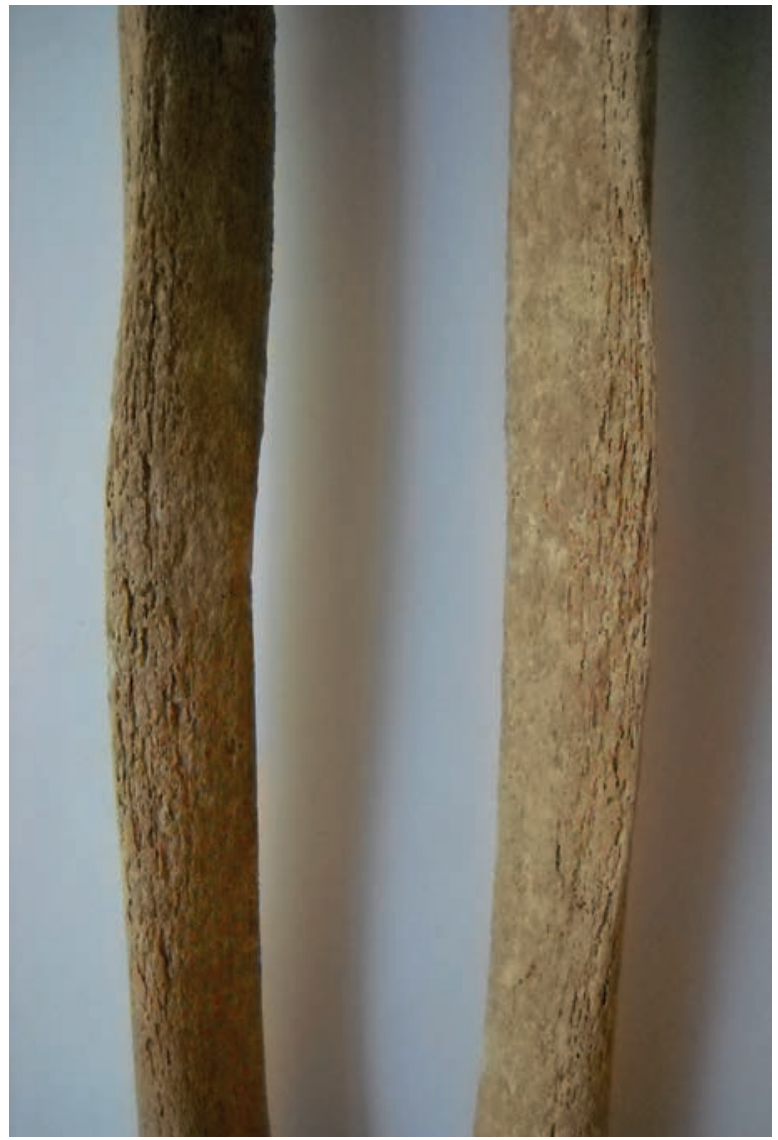

11. ábra. Gyulladásos nyomok sípcsonton 


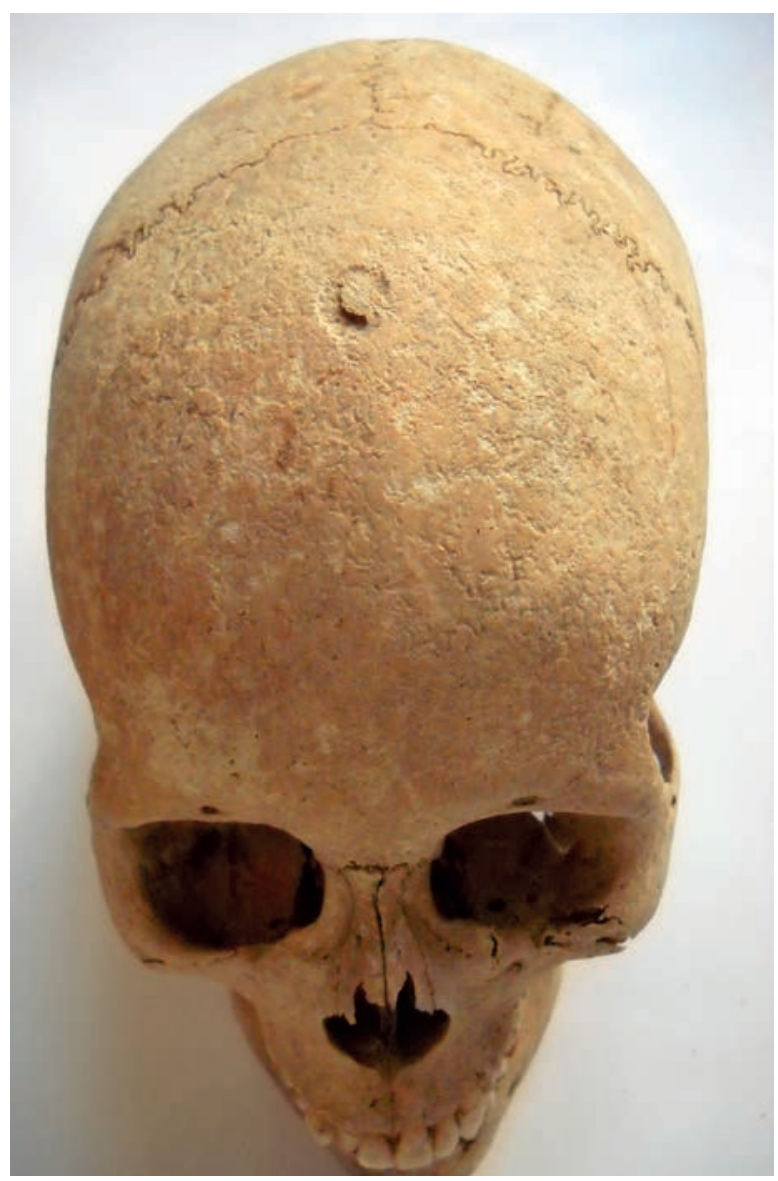

12. ábra. Jelképes trepanáció

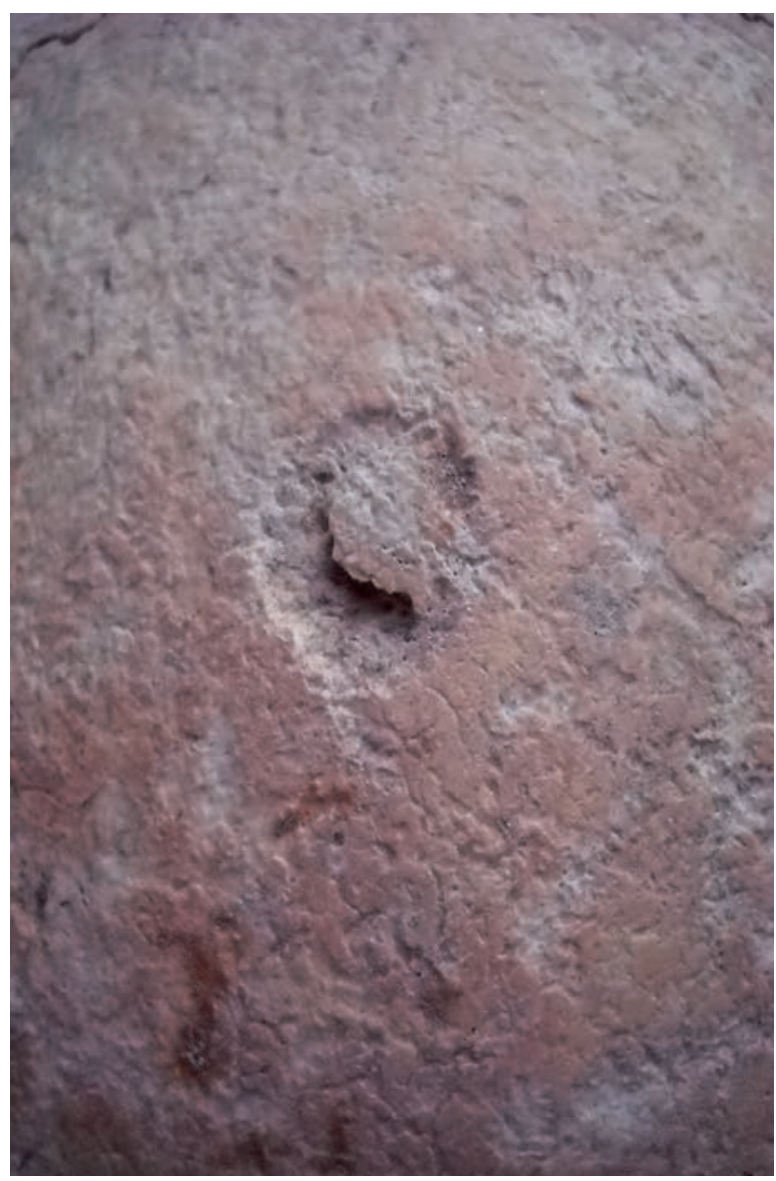

13. ábra. Jelképes trepanáció

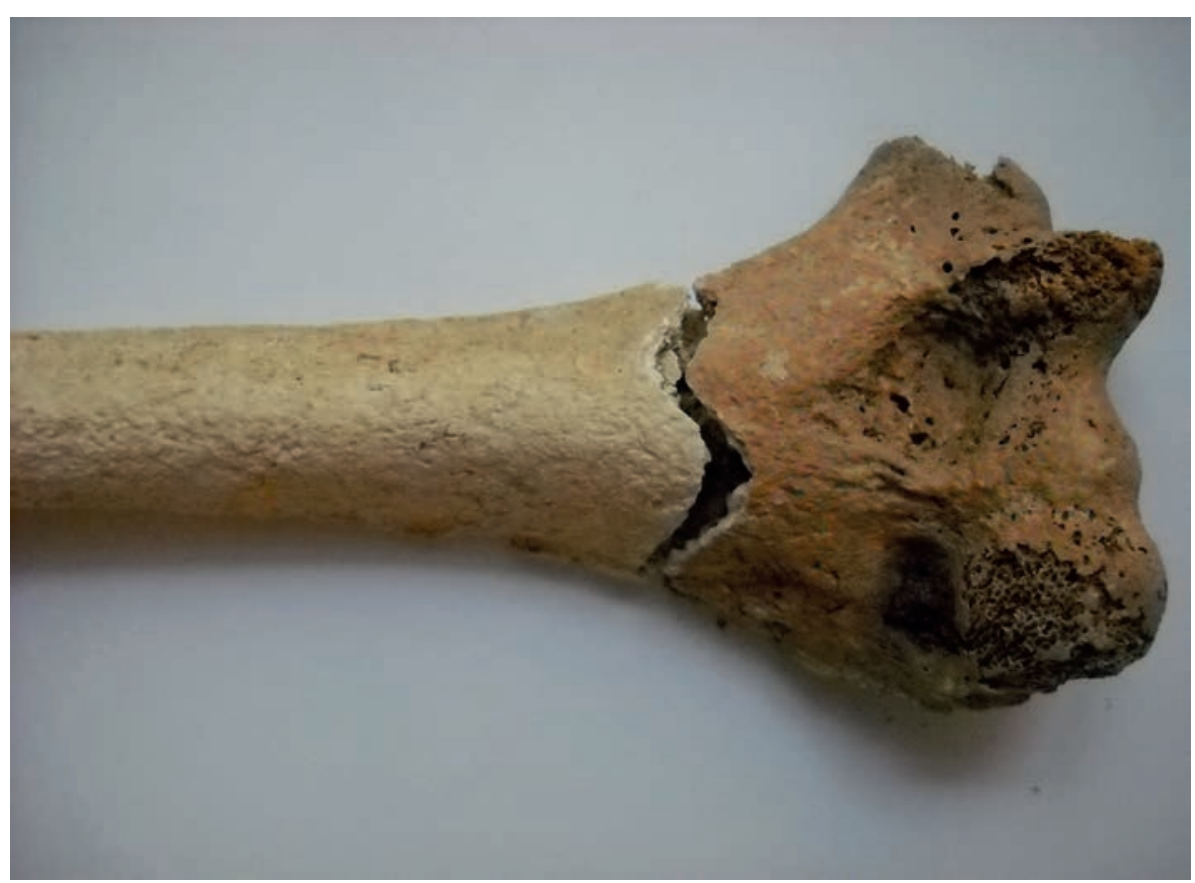

14. ábra. Felkarcsont régi törése - sírrablás nyoma 


\section{Irodalom}

ACSÁDI - NemESKÉRI 1970 Acsádi, György - Nemeskéri, János: History of human life span and mortality. Budapest, 1970.

ÉRY 1992 Éry Kinga: Útmutató csontvázleletek vizsgálatához. ELTE TTK, Kézirat, Budapest, 1992.

ÉRY 1994 Éry Kinga: A Kárpát-medence embertani képe a honfoglalás korában. In: Kovács László (szerk.): Honfoglalás és régészet. A honfoglalásról sok szemmel l. Budapest, 1994. 217-224, 291-302.

Knussmann 1988 Knußmann, Rainer: Anthropologie I. Stuttgart-New York, 1988.

LIPTÁK 1980 Lipták Pál: Embertan és emberszármazástan. Budapest, 1980. 254-302.

MARCSIK ET AL. 2009 Marcsik Antónia - Molnár Erika - Ősz Brigitta - Donoghue, Helen - Zink, Albert - Pálfi György: Adatok a lepra, tuberculosis és syphilis magyarországi paleopatológiájához. Folia Anthropologica 8. 5-34.

NeMESKÉRI 1941 Nemeskéri János: Érsekújvár-Naszvad határában előkerült honfoglaláskori csontvázak embertani vizsgálata. Folia Archaeologica 3-4. 225-230.

NemESKÉRI - ÉRY - KRALovÁnSZKY 1960 Nemeskéri János - Éry Kinga - Kralovánszky Alán: A magyarországi jelképes trepanáció. Anthropologiai Közlemények 4. 3-30.

NevizAnsky - RAtimORSKa 1991 Nevizansky, Gabriel - Ratimorska, Priska: Staromadarské kostrové pohrebiská z 10. storocia v Nesvadoch. Archeologické Rozhledy 43. 259-280.

Sృøvold 1990 Sjøvold, Torstein: Estimation of stature from long bones utilizing the line of organic correlation. Human Evolution 5. 431-447.

SzÖKE 1941 Szőke Béla: Honfoglaláskori magyar sírok Naszvadon. Folia Archaeologica 3-4. 214-224.

SzŐke 1962 Szőke Béla (szerk.): Régészeti Tanulmányok II. A Közép-Duna-Medence magyar honfoglalás- és kora Árpád-kori sírleletei. Budapest, 1962.

VÁRADI ET AL. 2015 Váradi Orsolya Anna - Horváth Orsolya - Marcsik Antónia - Molnár Erika - Pálfi György - Bereczki Zsolt: Különleges formájú jelképes trepanációk a Dél-Alföldről. Anthropologiai Közlemények 56. 91-104.

VondRÁKOVÁ 1993 Vondráková Mária: Some cases of skull's trephinations and traumas from middle ages cemeteries in Slovakia. In: Pavúk Juraj (ed.): Actes du XIle Congrés International des Sciences Préhistoriques et Protohistoriques. I. Bratislava. 192-196. 